\title{
Heat shock increases oxidative stress to modulate growth and physico-chemical attributes in diverse maize cultivars**
}

\author{
Iqbal Hussain 1,3*, Muhammad Arslan Ashraf ${ }^{1}$, Rizwan Rasheed ${ }^{1}$, Muhammad Iqbal $^{1}$, \\ Muhammad Ibrahim², and Shamila Ashraf ${ }^{1}$ \\ ${ }^{1}$ Department of Botany, Government College University, Faisalabad-38000, Pakistan \\ ${ }^{2}$ Department of Applied Chemistry and Biochemistry, Government College University, Faisalabad-38000, Pakistan \\ ${ }^{3}$ Department of Environmental Life Sciences, Graduate School of Life Sciences, Tohoku University, Sendai 980-8577, Japan
}

Received February 11, 2016; accepted October 17, 2016

\begin{abstract}
A b s t r a c t. The present investigation was conducted to appraise the physiochemical adjustments in contrasting maize cultivars, namely, PakAfgoi (tolerant) and EV-5098 (sensitive) subjected to heat shock. Seven-day-old seedlings were exposed to heat shock for different time intervals $(1,3,6,24,48$ and $72 \mathrm{~h})$ and data for various physiochemical attributes determined to appraise time course changes in maize. After $72 \mathrm{~h}$ of heat shock, the plants were grown under normal conditions for $5 \mathrm{~d}$ and data for different growth attributes and photosynthetic pigments recorded. Exposure to heat shock reduced growth and photosynthetic pigments in maize cultivars. The plants exposed to heat shock for up to $3 \mathrm{~h}$ recovered growth and photosynthetic pigments when stress was relieved. A time course rise in the relative membrane permeability, hydrogen peroxide $\left(\mathrm{H}_{2} \mathrm{O}_{2}\right)$ and malondialdehyde contents was recorded particularly in the EV-5098 indicating that heat shock-induced oxidative stress. Activities of different enzymatic antioxidants greatly altered due to heat shock. For instance, an increase in superoxide dismutase activity was recorded in both maize cultivars. The activity of ascorbate peroxidase was greater in Pak-Afgoi. However, the peroxidase and catalase activities were higher in plants of EV-5098. Heat shock caused a significant rise in the proline and decline in the total free amino acids. Overall, the performance of Pak-Afgoi was better in terms of having lesser oxidative damage and greater cellular levels of proline. The results suggested that oxidative stress indicators (relative membrane permeability, $\mathrm{H}_{2} \mathrm{O}_{2}$ and malondialdehyde) and proline can be used as markers for heat shock tolerant plants.

$\mathrm{K}$ e y w o r d s: antioxidant enzymes, chlorophyll pigments, growth, heat shock, lipid peroxidation and maize
\end{abstract}

\section{INTRODUCTION}

High temperature (HT) is a potential threat to plant growth, metabolism, and crop production globally. Plant growth and development involve many biochemical reac-

*Corresponding author e-mail: driqbal@gcuf.edu.pk

**This work was partially supported by the grants from Higher Education Commission (HEC), Islamabad, Pakistan through Project No. PM-IPFP/HRD/HEC/2011/0579, 2011-2014. tions that are sensitive to HT stress. Plant responses to HT vary with the degree, duration and the plant type (Hasanuzzaman et al., 2013). The global air temperatures are expected to raise $2.0^{\circ} \mathrm{C}$ per decade, which could lead to temperatures $1.8-4.0^{\circ} \mathrm{C}$ greater by the end of this century mostly due to greenhouse gas emissions (IPCC, 2007). With global warming, plant HT injury is becoming a serious problem. In wheat, maize and barley, there is a negative correlation between the plant yields and HT stress (Lobell and Field, 2007). The seed germination, seedling emergence and its establishment is extremely affected by HT in a number of plant species, for example, pearl millet and maize (Ashraf and Hafeez, 2004). High temperature changed the seed composition, seed protein expression profiles and reduced the seed germination and vigor, and thus appeared to determine the seed quality attributes (Egli et al., 2005). High temperature stress lowers the activity of specific enzymes and leads to reduce the synthesis of proteins in germinating embryos of the maize (Riley, 1981). High temperature alters the photosynthetic acclimation and physiological processes directly and modifies the pattern of development indirectly. Heat shock (HS) stress causes various, and often severe changes in plant growth, development, physiological processes and final economic yield in different crop species (Hasanuzzaman et al., 2013).

High temperature induces the overproduction of reactive oxygen species (ROS) such as superoxide radical $\left(\mathrm{O}^{2}\right)$, singlet oxygen $\left({ }^{1} \mathrm{O}_{2}\right)$, hydrogen peroxide $\left(\mathrm{H}_{2} \mathrm{O}_{2}\right)$ and hydroxyl radical $\left(\mathrm{OH}^{-}\right)$(Savicka and Škute, 2010), and consequently causes an increase in the peroxidative processes,

(C) 2016 Institute of Agrophysics, Polish Academy of Sciences 
a decrease in the saturated fatty acids, and an increase in the unsaturated fatty acid contents in the membranes of several plant species (Rodríguez et al., 2005). The ROS are strong oxidizing agents that cause cell death by lipid peroxidation, oxidation of proteins and induce substantial damage to DNA (Hasanuzzaman et al., 2013). Plants are able to circumvent ROS-induced oxidative stress through the antioxidant defense system. The antioxidant system restricts and alleviates oxidative damage and increases resistance to environmental stresses that often correlate with an efficient antioxidant system. The activities of antioxidant enzymes such as superoxide dismutase (SOD), peroxidase (POD), catalase (CAT), glutathione peroxidase (GPX), ascorbate (APX) and glutathione reductase (GR) serve as an important indicator of an antioxidant defense mechanism (Chakraborty and Pradhan, 2011). The cellular injury is evaluated by measuring the leakage of electrolytes in order to assess the severity of existing stress (Savicka and Škute, 2010). Membrane stability is positively related to yield performance under HS stress (Rahman et al., 2009). To repair the inhibitory effects of ROS, plants make use of antioxidant defense machinery that includes enzymatic and non-enzymatic antioxidant system that is involved in the detoxification of ROS. Of various enzymatic antioxidants, SOD converts superoxide to $\mathrm{H}_{2} \mathrm{O}_{2}$ in different sub-cellular compartments. $\mathrm{H}_{2} \mathrm{O}_{2}$ is further scavenged by CAT, APX and other non-enzymatic antioxidants, including tocopherols, carotenoids, ascorbate, etc. (Weisany et al., 2012).

The malondialdehyde (MDA) or thiobarbituric acid reactive substances (TBARs) are one of the major transitional compounds of the disintegration of polyunsaturated fatty acids in biomembranes and have been extensively used as an indices of oxidative processes (Balakhnina et al., 2005). Moreover, MDA levels are higher in heat-sensitive plants than those of heat-tolerant plants (Hurkman et al., 2009). Proline, an amino acid, which is increased in response to diverse types of abiotic stresses (Kaushal et al., 2011), has several roles in turgor generation, osmotic adjustment, storage of carbon and nitrogen, and cellular redox potential. Furthermore, proline could maintain the enzyme structure and activity (Kaushal et al., 2011) and thus protect membrane integrity (Hayat et al., 2012).

Maize (Zea mays L.) is the third important cereal after wheat and rice. It is extensively grown in temperate, subtropical and tropical regions of the world. Maize shows optimum growth at $28-31{ }^{\circ} \mathrm{C}$. Being a rich source of nutrition $(71 \%$ starch, $11.1 \%$ protein, $8.4 \%$ fiber, and $4.6 \%$ edible oil, $4.3 \%$ sugar and $1.3 \%$ ash), maize is a major source of food, sugar, ethanol, biofuels, cooking oil, maize glutin and animal feed all over the globe (Iken et al., 2002). Since maize growth is severely hampered by fluctuations in the temperature, the present experiment was conducted to highlight the underlying physiochemical adjustments modulating growth of maize plants subjected to HS. Both the synthetic cultivars viz. Pak-Afgoi and EV-5098 are relat- ed to each other in terms of their breeding. Furthermore, the $c v$. Pak-Afgoi is relatively tolerant than $c v$. EV-5098 (Perveen et al., 2013; Rasheed et al., 2015).

Thus, the aim of this study was to assess whether heat shock-mediated physiochemical adjustments are responsible for heat tolerance in maize.

\section{MATERIAL AND METHODS}

The seeds of two genetically diverse maize (Zea mays L.) cultivars, namely, Pak-Afgoi (heavy metals, temperature, drought and salt tolerant) and EV-5098 (abiotic stress sensitive) were obtained from Maize and Millets Research Institute (MMRI), Yousafwala, Sahiwal, Pakistan. The experiment was conducted in the Botanical Garden, Department of Botany, Government College University, Faisalabad, Pakistan (latitude 29.830 N, longitude 72.811 $\mathrm{E}$ and altitude $214 \mathrm{~m}$ ). The seeds were disinfected with $0.1 \% \mathrm{HgCl}_{2}$ solution for $15 \mathrm{~min}$ to avoid fungus and other contamination. Then washed with distilled water before sowing in the clay pots (dimensions $14 \mathrm{~cm}$ high, circumference of $19 \mathrm{~cm}$ at top and $7 \mathrm{~cm}$ at the bottom) contained $1 \mathrm{~kg}$ sand. Ten seeds were sown in each pot and placed in a plant growth chamber (Model Grow 600-HR, Ingclimas, Spain) set at day/night temperature $28^{\circ} \mathrm{C} / 22^{\circ} \mathrm{C}$, respectively. After germination, six healthy and uniform seedlings of equal size for each treatment were retained. Sevenday-old maize seedlings were transferred from the control temperature regime $\left(28^{\circ} \mathrm{C} / 22^{\circ} \mathrm{C}\right.$, day/night) to the high temperature regime $\left(41^{\circ} \mathrm{C} / 36^{\circ} \mathrm{C}\right.$, day/night $)$ in another similar plant growth chamber. The plants were irrigated with half strength hoagland nutrient solution whenever needed to keep moisture contents over field capacity so as to prevent the drought stress. The other growth conditions were: $14 / 10 \mathrm{~h} \mathrm{light} /$ dark period, $400 \mu \mathrm{mol} \mathrm{m}^{-2} \mathrm{~s}^{-1}$ photosynthetically active radiation (PAR) and the mean relative humidity $(64 \pm 4 \%)$. Arrangement of the experiment was completely randomized design with three replicates per treatment. After HS of three days, the plants were grown at normal temperatures and different growth attributes and photosynthetic pigments were determined after five days of stress relief. The third fully mature leaf was sampled after 1, 3, 6, 24,48 , and $72 \mathrm{~h}$ of HS to determine time course changes in different physiochemical attributes.

Leaf area was taken of intact plants as maximum leaf length $\times$ maximum leaf width $\times 0.68$ (correction factor computed for all levels). After drying in an oven at $70^{\circ} \mathrm{C}$ for about $72 \mathrm{~h}$, shoot and root dry weights were recorded. The other plant samples were preserved in cooling chamber at $-20^{\circ} \mathrm{C}$. 
The chlorophyll $\mathrm{a}$ and $\mathrm{b}(\mathrm{Chl} a$ and $b)$ contents were quantified by the method of Yoshida et al. (1976). $5 \mathrm{ml}$ of acetone $(80 \%)$ was used to homogenize the $0.1 \mathrm{~g}$ of fresh leaf material. Then the supernatant was used to measure absorbance at different wavelengths $(480,645$ and $663 \mathrm{~nm})$ using UV-VIS spectrophotometer (Hitachi U-2910). Leaf carotenoids were quantified by using the procedure of Davies (1976). Chlorophyll and total carotenoid content were calculated on the dry weight basis and expressed as $\mathrm{mg} \mathrm{g}^{-1}$ dry weight of a leaf.

Leaf tissues were collected in the test tubes containing distilled water $(10 \mathrm{ml})$ and vortexed for $5 \mathrm{~s}$. The electrical conductivity $\left(\mathrm{EC}_{0}\right)$ of the filtrate was measured. Then $\mathrm{EC}_{1}$ of the filtrate was measured after $24 \mathrm{~h}$ by keeping them at $4^{\circ} \mathrm{C}$. The filtrate was autoclaved for $15 \mathrm{~min}$ for measuring $\mathrm{EC}_{2}$. The percentage of ions leakage was calculated from the equation of Yang et al. (1996).

Leaf hydrogen peroxide levels were quantified using the procedure of Velikova et al. (2000). Fresh leaf tissue $(0.15 \mathrm{~g})$ was homogenized ground in $1 \mathrm{ml}$ of TCA $(0.1 \%)$ $(\mathrm{w} / \mathrm{v})$. Centrifuged the homogeneous material at $10000 \mathrm{~g}$ for $10 \mathrm{~min}$ for collection of supernatant. The mixture of supernatant and potassium phosphate buffers $(0.5 \mathrm{ml}$ each) reacted with $1 \mathrm{ml}$ of potassium iodide $(\mathrm{KI})$ solution $(1 \mathrm{M})$. Vortexed the mixture thoroughly. Then absorbance was noted at $390 \mathrm{~nm}$ by using UV-VIS spectrophotometer and TCA $(0.1 \%)$ solution was used as blank. The hydrogen peroxide was determined from the standard curve of known concentration of hydrogen peroxide and the values were expressed as $\mu \mathrm{mol} \mathrm{g}^{-1}$ fresh weight (FW).

Malondialdehyde (MDA) contents were estimated using the procedure (Heath and Packer, 1968). One $\mathrm{ml}$ of $5 \%$ TCA solution ( $\mathrm{w} / \mathrm{v}$ ) was used to homogenize the $0.1 \mathrm{~g}$ of fresh leaf material. Centrifuged the homogeneous material at $12000 \mathrm{~g}$ for collection of supernatant and $1 \mathrm{ml}$ of it was reacted with $1 \mathrm{ml}$ of $20 \%$ TCA prepared in $0.5 \%(\mathrm{w} / \mathrm{v})$ TBA. This mixture was heated at $95^{\circ} \mathrm{C}$ for $30 \mathrm{~min}$ in a water bath. After heating, the mixture was centrifuged at $7500 \mathrm{~g}$ for $5 \mathrm{~min}$. The absorbance of material at 532 and $600 \mathrm{~nm}$ was noted using TCA (5\%) as a blank. MDA contents were calculated using an extinction coefficient of $155000 \mathrm{nmol}$ $\mathrm{mol}^{-1}$. The MDA concentration was calculated according to the following formula:

$$
\left.\operatorname{MDA}(\mathrm{nmol} \mathrm{ml})^{-1}\right)=\left[\left(A_{532}-A_{600}\right) / 155000\right] 10^{6},
$$

where: $\mathrm{A}_{532}$ and $\mathrm{A}_{600}$ are the optical densities measured at $532,600 \mathrm{~nm}$, respectively, with UV-VIS spectrophotometer (Hitachi U-2910).

Free proline was determined using the method of Bates et al. (1973). 3\% aqueous sulphosalicylic acid $(5 \mathrm{ml})$ was used to homogenize the $0.1 \mathrm{~g}$ of fresh leaf material. Mixed acid ninhydrin $(1 \mathrm{ml})$ and glacial acetic acid $(1 \mathrm{ml})$ with filterate $(1 \mathrm{ml})$ in a test tube. Heating the mixture at $100^{\circ} \mathrm{C}$ for $10 \mathrm{~min}$ and cooled in an ice bath. Toluene $(4 \mathrm{ml})$ was added to extract the mixture and vortexed for $20 \mathrm{~s}$ and cooled.
The absorbance of material was measured at $532 \mathrm{~nm}$ with UV-VIS spectrophotometer (Hitachi U-2910. Free proline contents were determined from the standard curve of known concentration. The amount of free proline was calculated on a dry weight (DW) basis and expressed as $\mu \mathrm{mol} \mathrm{g}^{-1}$ dry weight of a leaf.

Total free amino acids were determined by using the ninhydrin method of Hamilton and Van Slyke (1973). Phosphate buffer ( $\mathrm{pH}$ 7.0) was used to homogenize the $0.1 \mathrm{~g}$ of fresh leaf material. In $25 \mathrm{ml}$ test tube, $1 \mathrm{ml}$ extract was taken, and then $1 \mathrm{ml}$ of $10 \%$ pyridine and $1 \mathrm{ml}$ of $2 \%$ ninhydrin solution was added in each test tube. And heated the test tubes for $30 \mathrm{~min}$ in a water bath. The volume was maintained up to $50 \mathrm{ml}$ by using distilled water in each tube. Optical density was measured at $570 \mathrm{~nm}$ by using UV-VIS spectrophotometer (Hitachi U-2910, Tokyo, Japan). The amount of total free amino acids was calculated from the standard curve of Lucine at $570 \mathrm{~nm}$ and expressed as $\mathrm{mg} \mathrm{g}^{-1}$ dry weight of a leaf.

The anthocyanin contents were determined by the method of Hodges and Nozzolillo (1996). Fresh leaf material $(0.1 \mathrm{~g})$ of the sample was crushed in acidified methanol $(2 \mathrm{ml})$ with the help of pestle and mortar. Then materials transferred to the centrifuge tubes, and heated them in a water bath at $50^{\circ} \mathrm{C}$ for one hour. Centrifuge the materials at $12000 \mathrm{~g}$ in the centrifuge machine for $15 \mathrm{~min}$. The absorbance was measured at 540 and $600 \mathrm{~nm}$ by using UV-VIS spectrophotometer (Hitachi U-2910, Tokyo, Japan). The amount of total anthocyanin contents was calculated in the original sample and expressed as $\mathrm{mg} \mathrm{g}^{-1}$ dry weight of a leaf.

Superoxide dismutase (SOD) was assayed using the procedure given by Gong et al. (2005) with minor modifications. The reaction solution $(3 \mathrm{ml})$ contained $50 \mu \mathrm{M}$ nitroblue tetrazolium (NBT), $1.3 \mu$ M riboflavin, $13 \mathrm{mM}$ methionine, $75 \mathrm{mM}$ ethylenediaminetetraacetic acid, $50 \mathrm{mM}$ potassium phosphate buffer $(\mathrm{pH} 7.8)$ and $20-50 \mathrm{ml}$ of enzyme extract. The test tubes containing the reaction solution were irradiated under light (15 fluorescent lamps) at $78 \mu \mathrm{mol} \mathrm{m}^{-2} \mathrm{~s}^{-1}$ for $15 \mathrm{~min}$. The absorbance of the solution at $560 \mathrm{~nm}$ was read using a spectrophotometer (IRMECO U2020, Geesthact, Germany). One unit of SOD activity was defined as the amount of enzyme that inhibited $50 \%$ of NBT photo-reduction. POD and CAT activities were estimated according to the protocol of Cakmark et al. (1993). The reaction mixture $(3 \mathrm{ml})$ contained guaiacol $(20 \mathrm{mM})$, phosphate buffer $(50 \mathrm{mM})$ contained $\mathrm{pH}(5.0), \mathrm{H}_{2} \mathrm{O}_{2}(40 \mathrm{mM})$ and enzyme extract $(0.1 \mathrm{ml})$ for POD. Change in absorbance at $470 \mathrm{~nm}$ was recorded after every $20 \mathrm{~s}$ for $2 \mathrm{~min}$. The activity of enzyme was estimated in units $(U=1 \mathrm{mM}$ of $\mathrm{H}_{2} \mathrm{O}_{2}$ reduction min $\mathrm{mg}^{-1}$ protein). CAT reaction mixture $(3 \mathrm{ml})$ included phosphate buffer $(50 \mathrm{mM})$ $(\mathrm{pH} 7.0), \mathrm{H}_{2} \mathrm{O}_{2}(5.9 \mathrm{mM})$ and enzyme extract $(0.1 \mathrm{ml})$. Enzyme extract was added to mixture to start the reaction. Change in absorbance after every $20 \mathrm{~s}$ was recorded for $2 \mathrm{~min}$ at $240 \mathrm{~nm}$. Leaf APX activity was estimated by 
using the procedure of Krivosheeva et al. (1996). The reaction mixture $(1 \mathrm{ml})$ comprised $\mathrm{H}_{2} \mathrm{O}_{2}(0.1 \mathrm{mM})$, potassium phosphate buffer $(50 \mathrm{mM})(\mathrm{pH} 7.0)$, ascorbic acid $(0.5 \mathrm{mM})$ and enzyme extract $(200 \mu \mathrm{l})$. The absorbance of mixture was noted as reduced at $290 \mathrm{~nm}$ and the correction was done by $\mathrm{H}_{2} \mathrm{O}_{2}$. The activity of these enzymes was expressed in $\mathrm{U} / \mathrm{mg}$ protein.

Data for all variables were subjected to analysis of variance (ANOVA) using a COSTAT computer package (Cohort Software, Berkeley, CA, USA). The mean values were compared with the Duncan Multiple Range test $(p<0.05)$. Correlations of different growth and biochemical attributes with HS were determined using XLSTAT version 7.5.2 (Addinsoft SARL, 2004, Paris, France).

\section{RESULTS AND DISCUSSION}

Both maize cultivars subjected to HS for varying durations $(1,3,6,24,48$ and $72 \mathrm{~h})$ had a prominent $(\mathrm{p} \leq 0.001)$ decline in different growth attributes such as shoot and root dry masses, and leaf area (Table 1). The cultivar Pak-Afgoi had a greater shoot and root dry masses and leaf area when exposed to HS for 6 and $24 \mathrm{~h}$ and the minimal values for these attributes were evident after $72 \mathrm{~h}$ of HS. In contrast, EV-5098 had a greater shoot and root dry masses when subjected to HS for 24 and $48 \mathrm{~h}$, while the greater leaf area was recorded under HS for 6 h. Overall, EV-5098 was much more sensitive to HS with respect to growth attributes as compared with Pak-Afgoi (Fig. 1). Environmental changes, especially changes in the temperature beyond optimal could affect crop growth and productivity severely in agricultural environments. In the present study, a time dependent change in shoot and root dry masses were observed in both maize cultivars exposed to HS.

The results suggested that increase in temperature might have enhanced the synthesis and translocation of photoassimilates to developing sinks and thus increased growth initially. However, further increase in temperature acted as a dehydrative force that caused evapo-transpiration and reduced the growth (Fig. 1). The loss of water is a major factor affecting the metabolic activities in plants (Iqbal and Ashraf, 2010).

Exposure of maize plants to HS for $1 \mathrm{~h}$ increased photosynthetic pigments (Chl. a and b) and total carotenoid contents, while other subsequent increase in exposure time of plants to HS (3, 6, 24, 48 and $72 \mathrm{~h}$ ) caused a consistent decline in these variables. Maximal values for photosynthetic pigments and carotenoids were recorded in Pak-Afgoi after $1 \mathrm{~h}$ of HS. Moreover, increase in exposure time to HS caused a sharp decline in these attributes in both maize cultivars (Fig. 2 and Table 1).

Heat shock has been shown to enhance the stomatal closure and inhibit the photosynthesis via chlorophyll degradation in plants. Decline in chlorophyll contents in response to heat stress has been reported in sorghum
(Gosavi et al., 2014). Reduction in chlorophyll contents is attributed to the disintegration of the structure and function of chloroplasts. Heat stress in plants $\left(42^{\circ} \mathrm{C}\right)$ has been shown to inhibit de novo synthesis of chlorophyll. Moreover, thylakoid components are broken down in plants subjected to heat stress. Maintenance of greater endogenous levels of chlorophyll is taken as an indicator for heat stress tolerance in plants (Farooq et al., 2011). In the present study, Pak-Afgoi had higher endogenous levels of chlorophyll than that of EV-5098 (Fig. 2). This information could be utilized in breeding programs aimed at improving heat tolerance of plants.

Maize plants had accumulated substantial levels of proline when exposed to HS for 1, 3, 6, 24, 48 and $72 \mathrm{~h}$. There was a consistent increase in endogenous levels of proline with increase in exposure time to HS in both maize cultivars. The response of maize cultivars with respect to proline was not the same $(\mathrm{p} \leq 0.001)$ under HS (Table 1$)$. For instance, Pak-Afgoi exhibited maximal accumulation of proline than that of EV-5098 (Fig. 3).

Total amino acid contents decreased in both maize cultivars subjected to HS for varying durations except for $1 \mathrm{~h}$, where a substantial increase in this variable was recorded. The response of two maize cultivars was not the same $(p \leq 0.001)$ with respect to this attribute (Table 1). For example, maximal values for total free amino acids were evident in Pak-Afgoi (Fig. 3). Exposure of maize plants to HS for different durations resulted in a substantial increase and then decline in the anthocyanin contents in EV-5098 while it did not affect in Pak-Afgoi. The response of both maize cultivars was different with respect to this variable. For example, EV-5098 possessed elevated endogenous contents of anthocyanin when exposed to HS (Fig. 3).

Plants exposed to dehydration or osmotic stress conditions showed the accumulation of compatible solutes. The results of the present study are in agreement with the findings of an earlier researcher where environmental stresses, including HS cause a conspicuous rise in endogenous levels of proline in plants (Fig. 3). Proline protects plants against a number of ambitious stresses (Cvikrova et al., 2012). In this context, proline has been shown to induce tolerance in plants against chilling, heat, metals, drought and salt. This role of proline under diverse environmental conditions correlated with its function as compatible solute, being an uncharged molecule at neutral $\mathrm{pH}$, and greater solubility in water. Moreover, higher cellular levels of proline are not toxic to plants. Proline prevents the protein denaturation, thereby maintaining the integrity of membranes in heat-induced dehydration stress. Likewise, proline protects photosynthetic machinery of plants, and acts as a source of nitrogen, carbon and energy for plants during recovery from stress (Hayat et al., 2012). Moreover, accumulation of proline in response to HS stress could be attributed to the generation of reactive oxygen species (ROS). Proline is known to act as antioxidants as it scavenges ROS. It has 
T a b l e 1. Mean square values from ANOVA of data of some growth and biochemical attributes of two maize (Zea mays L.) cultivars under control $\left(28^{\circ} \mathrm{C}\right)$ and HS stress $\left(41^{\circ} \mathrm{C}\right)$ in a time course manner

\begin{tabular}{|c|c|c|c|c|c|}
\hline S.O.V. & $\mathrm{df}$ & SDW & RDW & Leaf area & Chl. a \\
\hline Cultivars (C) & 1 & $0.333 * * *$ & $0.348 * * *$ & $265.327 * * *$ & $1.659 * * *$ \\
\hline Harvest time (HT) & 5 & $0.009 * * *$ & $0.023 * * *$ & $10.664 * * *$ & $0.019 * * *$ \\
\hline Heat shock (HS) & 1 & $0.044 * * *$ & $0.041 * * *$ & $93.271 * * *$ & $0.058 * * *$ \\
\hline $\mathrm{C} \times \mathrm{HT}$ & 5 & $0.002 * * *$ & $0.006^{* * *}$ & $1.906 * * *$ & $0.066 * * *$ \\
\hline $\mathrm{C} \times \mathrm{HS}$ & 1 & $0.013 * * *$ & $0.00028 \mathrm{~ns}$ & $4.988 * * *$ & $0.040 * * *$ \\
\hline HT x HS & 5 & $0.012 * * *$ & $0.013 * * *$ & $4.382 * * *$ & $0.004 * * *$ \\
\hline C x HT x HS & 5 & $0.004 * * *$ & $0.006^{* * *}$ & $1.708 * * *$ & $0.005 * * *$ \\
\hline Error & 48 & 0.000014 & 0.00052 & 0.039 & 0.00031 \\
\hline LSD 0.05 & - & 0.237 & 0.256 & 1.379 & 0.153 \\
\hline S.O.V. & df & Chl.b & Carotenoids & RMP & MDA \\
\hline Cultivars (C) & 1 & $0.0213 * * *$ & $0.0420 * * *$ & $1917.37 * * *$ & $277.80 * * *$ \\
\hline Harvest time (HT) & 5 & $0.0081 * * *$ & $0.00017 * * *$ & $127.24 * * *$ & $45.13 * * *$ \\
\hline Heat shock (HS) & 1 & $0.0099 * * *$ & $0.00051 * * *$ & $211.07 * * *$ & $139.09 * * *$ \\
\hline $\mathrm{C} \times \mathrm{HT}$ & 5 & $0.0424 * * *$ & $0.0014 * * *$ & $2.944 * * *$ & $1.055 * * *$ \\
\hline $\mathrm{C} \times \mathrm{HS}$ & 1 & $0.00042 \mathrm{~ns}$ & $0.00075 * * *$ & $7.616 * * *$ & $32.08 * * *$ \\
\hline HT x HS & 5 & $0.00040 \mathrm{~ns}$ & $0.00027 * * *$ & $1.574 * * *$ & $0.81 * * *$ \\
\hline C x HT x HS & 5 & $0.0019 * *$ & $0.00027 * * *$ & $0.343 * * *$ & $0.86 * * *$ \\
\hline Error & 48 & 0.0002 & 0.0000149 & 0.064 & 0.180 \\
\hline LSD 0.05 & - & 0.237 & 0.256 & 1.379 & 0.153 \\
\hline S.O.V. & df & $\mathrm{H}_{2} \mathrm{O}_{2}$ & Proline & TFA & Anthocyanin \\
\hline Cultivars (C) & 1 & $174.752 * * *$ & $0.647 * * *$ & $0.052 * * *$ & $0.0031 * * *$ \\
\hline Harvest time (HT) & 5 & $21.416^{* * *}$ & $0.104 * * *$ & $0.006 * * *$ & $0.0124 * * *$ \\
\hline Heat shock (HS) & 1 & $174.270 * * *$ & $0.298 * * *$ & $0.014 * * *$ & $0.0110 * * *$ \\
\hline $\mathrm{C} \times \mathrm{HT}$ & 5 & $0.184 * * *$ & $0.031 * * *$ & $0.042 * * *$ & $0.0643 * * *$ \\
\hline $\mathrm{C} \times \mathrm{HS}$ & 1 & $63.086^{* * *}$ & $0.258 * * *$ & $0.027 * * *$ & $0.0379 * * *$ \\
\hline HT x HS & 5 & $0.495 * * *$ & $0.0104 * * *$ & $0.001 * * *$ & $0.0075 * * *$ \\
\hline $\mathrm{C} \times \mathrm{HT} \times \mathrm{HS}$ & 5 & $0.998 * * *$ & $0.0053 * * *$ & $0.001 * * *$ & $0.0059 * * *$ \\
\hline Error & 48 & 0.014 & 0.000387 & 0.0000372 & 0.00019 \\
\hline LSD 0.05 & - & 0.237 & 0.256 & 1.379 & 0.153 \\
\hline
\end{tabular}

$*$, **,*** significant at $0.05,0.01$ and 0.001 levels, respectively, ns - not significant, $\mathrm{RMP}$ - relative membrane permeability; $\mathrm{H}_{2} \mathrm{O}_{2}$ - hydrogen peroxide; MDA - malondialdehyde; TFA - total free amino acids; Chl. a - chlorophyll a; Chl. b - chlorophyll b; SOD superoxide dismutase; POD - peroxidase; CAT - catalase, SDW - shoot dry weight, RDW - root dry weight. 
T a b l e 1. Continuation

\begin{tabular}{|c|c|c|c|c|c|}
\hline S.O.V. & $\mathrm{df}$ & SDW & RDW & Leaf area & Chl. a \\
\hline Cultivars (C) & 1 & $0.333 * * *$ & $0.348 * * *$ & $265.327 * * *$ & $1.659 * * *$ \\
\hline Harvest time (HT) & 5 & $0.009^{* * *}$ & $0.023 * * *$ & $10.664 * * *$ & $0.019 * * *$ \\
\hline Heat-shock (HS) & 1 & $0.044 * * *$ & $0.041 * * *$ & $93.271 * * *$ & $0.058 * * *$ \\
\hline $\mathrm{C} \times \mathrm{HT}$ & 5 & $0.002 * * *$ & $0.006^{* * *}$ & $1.906^{* * *}$ & $0.066^{* * *}$ \\
\hline $\mathrm{C} \times \mathrm{HS}$ & 1 & $0.013 * * *$ & $0.00028 \mathrm{~ns}$ & $4.988 * * *$ & $0.040 * * *$ \\
\hline HT x HS & 5 & $0.012 * * *$ & $0.013 * * *$ & $4.382 * * *$ & $0.004 * * *$ \\
\hline C x HT x HS & 5 & $0.004 * * *$ & $0.006^{* * *}$ & $1.708 * * *$ & $0.005 * * *$ \\
\hline Error & 48 & 0.000014 & 0.00052 & 0.039 & 0.00031 \\
\hline LSD 0.05 & - & 0.237 & 0.256 & 1.379 & 0.153 \\
\hline
\end{tabular}
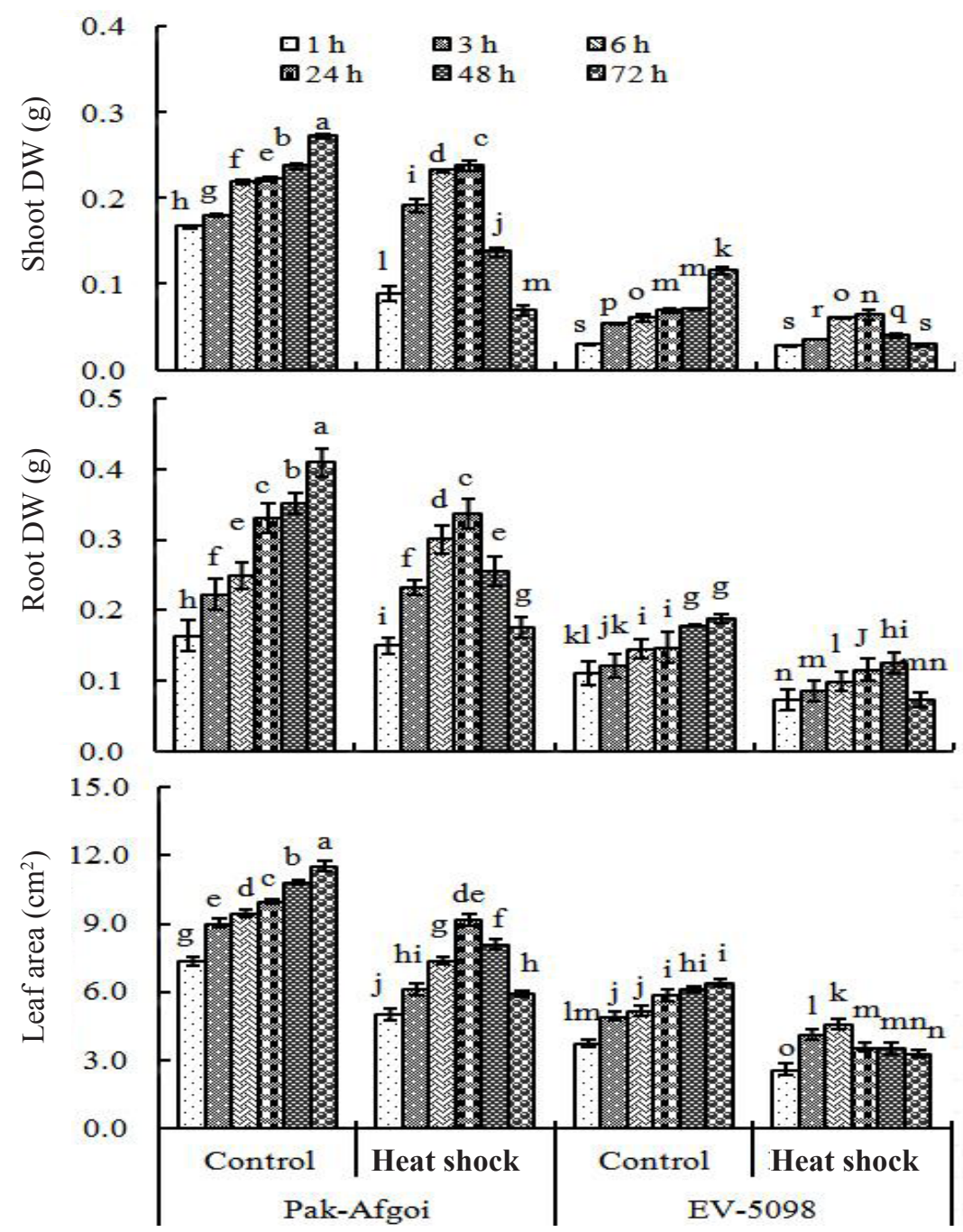

Fig. 1. Recovery of some growth attributes of two maize cultivars (Pak-Afgoi and EV-5098) grown under control $\left(28^{\circ} \mathrm{C}\right)$ and heat shock $\left(41^{\circ} \mathrm{C}\right)$ stress conditions. $(n=3$, mean $\pm \mathrm{SD})$. 

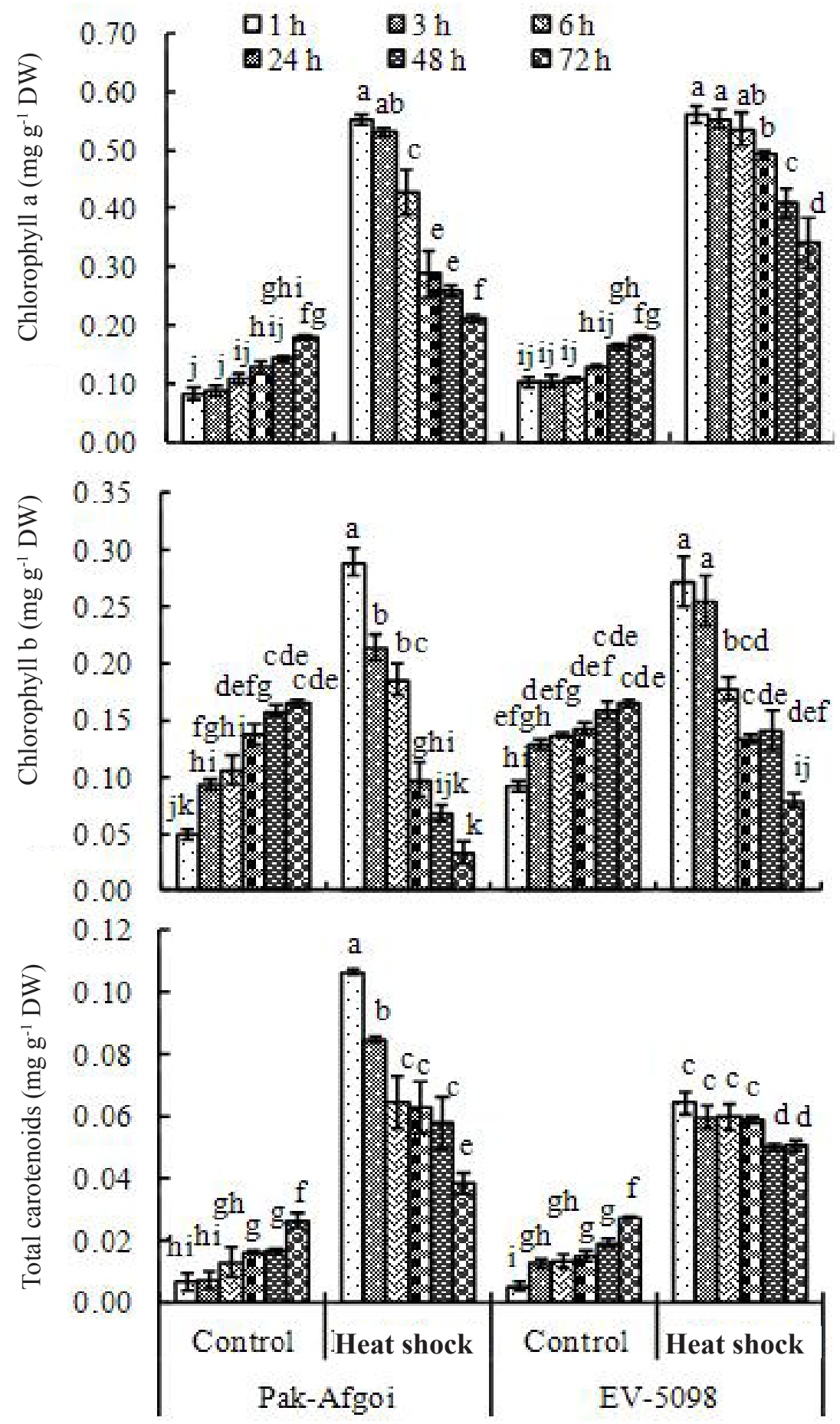

Fig. 2. Recovery of chlorophyll pigments of two maize cultivars (Pak-Afgoi and EV-5098) grown under control $\left(28^{\circ} \mathrm{C}\right)$ and heat shock $\left(41^{\circ} \mathrm{C}\right)$ stress conditions. $(\mathrm{n}=3$, mean $\pm \mathrm{SD})$. 

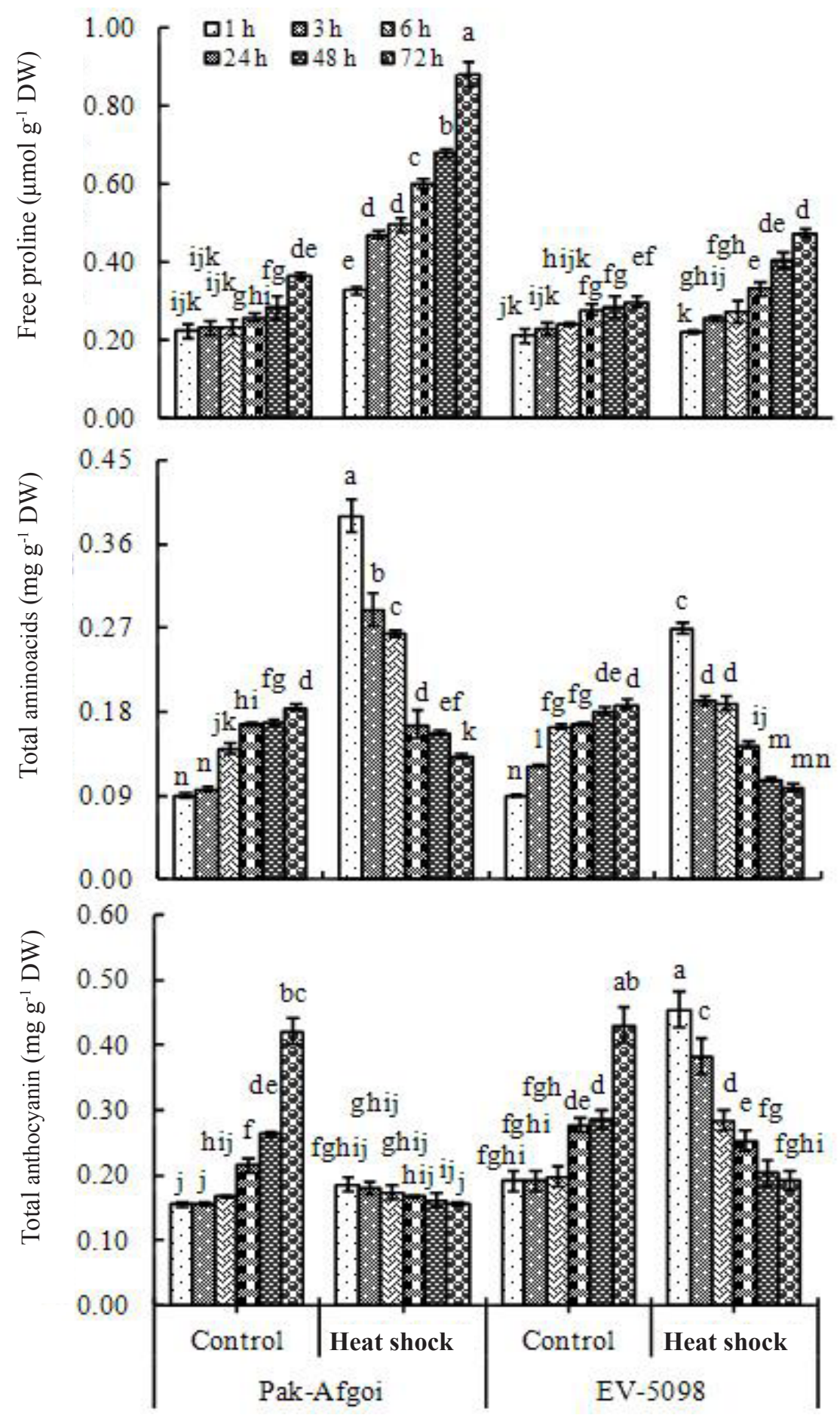

Fig. 3. Time course changes in total free proline, free amino acids and total anthocyanins contents in seedlings of two maize cultivars (Pak-Afgoi and EV-5098) grown under control $\left(28^{\circ} \mathrm{C}\right)$ and heat shock $\left(41^{\circ} \mathrm{C}\right)$ stress conditions. $(n=3$, mean $\pm \mathrm{SD})$. 

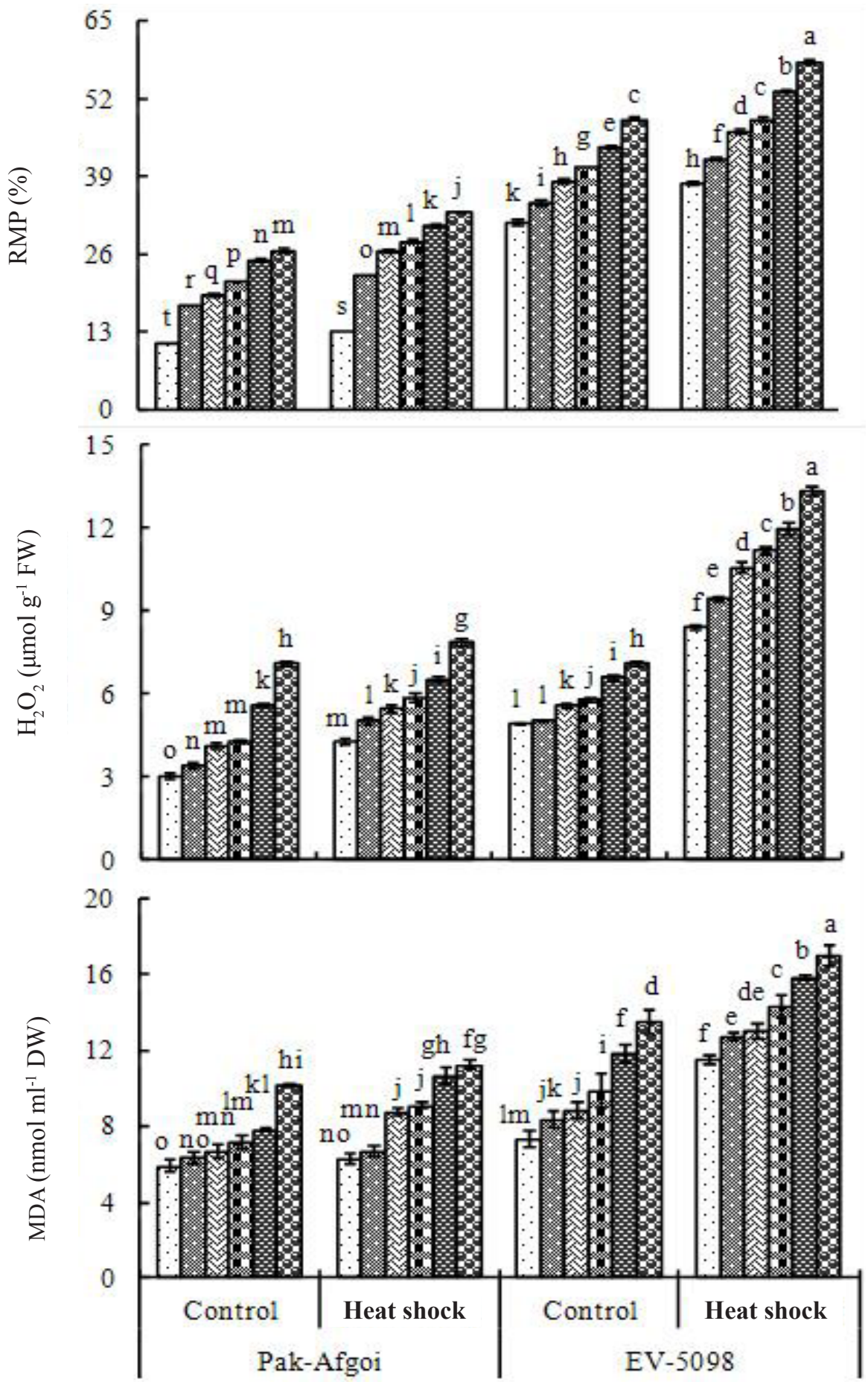

Fig. 4. Time course changes in RMP, $\mathrm{H}_{2} \mathrm{O}_{2}$, and MDA contents in seedlings of two maize cultivars (Pak-Afgoi and EV-5098) grown under control $\left(28^{\circ} \mathrm{C}\right)$ and heat shock $\left(41^{\circ} \mathrm{C}\right)$ stress conditions $(\mathrm{n}=3$, mean $\pm \mathrm{SD})$. 

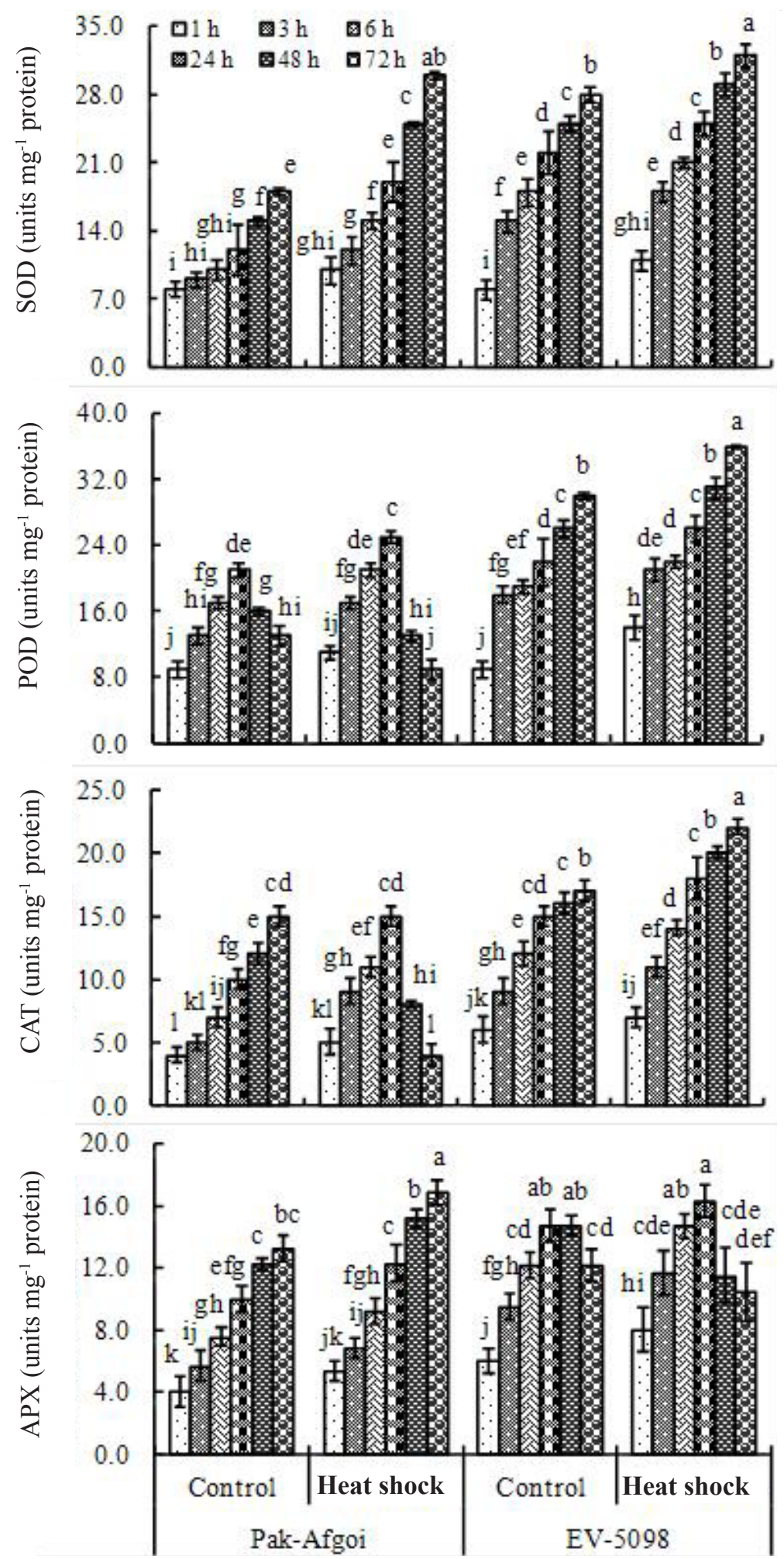

Fig. 5. Time course changes in antioxidants enzymes (SOD, POD, CAT and APX) activities in seedlings of two maize cultivars (PakAfgoi and EV-5098) grown under control $\left(28^{\circ} \mathrm{C}\right)$ and heat shock $\left(41^{\circ} \mathrm{C}\right)$ stress conditions $(\mathrm{n}=3$, mean $\pm \mathrm{SD})$. 
been reported in the literature that proline accumulation could be taken as a reliable indicator of tolerance to heat stress (Simon-Sarkadi et al., 2005).

There are many reports which show that anthocyanins act as non-enzymatic antioxidant, thereby protecting the plants against ROS-induced oxidative damage under heat stress. Loss of membrane integrity in terms of lipid peroxidation has been reported in anthocyanin deficient mutant of Arabidopsis (Agati et al., 2007). In the present investigation, higher anthocyanins contents were observed in maize plants of EV-5098 after one hour of HS (Fig. 3). Further HS gradually decreased anthocyanins contents in this cultivar. The sharp rise $\left(0.45 \mathrm{mg} \mathrm{g}^{-1} \mathrm{DW}\right)$ after HS for one hour in anthocyanins contents could be due to the genetic potential of the cultivar. In this context, Rasheed et al. (2015) recently showed much more higher contents of anthocyanins $\left(>5.5 \mathrm{mg} \mathrm{g}^{-1} \mathrm{DW}\right)$ in the same cultivar at the early vegetative stage. Furthermore, HS might had repressed the anthocyanins degrading enzymes such as polyphenoloxidase and glucosidase (Sarkis et al., 2013), thereby increasing anthocyanins in the cultivar. The increases in endogenous levels of total anthocyanins have been reported in plants under different abiotic stresses (Reshmi and Rajalakshmi, 2012). The anthocyanins acted as a defensive yardstick against abiotic stress in rice plants (Chutipaijit et al., 2011). The accumulation of anthocyanins could enhance tolerance to HS possibly by quenching free radicals (Mahmood et al., 2014).

Exposure of two maize cultivars to HS for different durations $(1,2,3,6,24,48$, and $72 \mathrm{~h})$ resulted in a significant $(\mathrm{p} \leq 0.001)$ rise in RMP, the endogenous levels of MDA and $\mathrm{H}_{2} \mathrm{O}_{2}$. The increase in these attributes was dose dependent. For instance, maximal values for these attributes were recorded when plants were exposed to HS for $72 \mathrm{~h}$. There existed a marker $(\mathrm{p} \leq 0.001)$ variable in both maize cultivars with respect to MDA, RMP and $\mathrm{H}_{2} \mathrm{O}_{2}$ under HS stress (Table 1). Plants of Pak-Afgoi accumulated lesser levels of RMP, MDA and $\mathrm{H}_{2} \mathrm{O}_{2}$ than those in the EV-5098. The rise in RMP, MDA and $\mathrm{H}_{2} \mathrm{O}_{2}$ in response to HS was almost negligible as compared to that in control plants of Pak-Afgoi. In contrast, a significant increase in these attributes was recorded in EV-5098 (Fig. 4).

Heat stress causes enhanced generation of ROS including $\mathrm{O}_{2}^{-},{ }^{1} \mathrm{O}_{2}, \mathrm{H}_{2} \mathrm{O}_{2}$ and $\mathrm{OH}^{-}$. A higher level of ROS causes lipid peroxidation, thereby modifying the membrane functions. Higher cellular levels of MDA and $\mathrm{H}_{2} \mathrm{O}_{2}$ result in ion leakage (Gill and Tuteja, 2010). Likewise, we have also found a positive association of MDA and $\mathrm{H}_{2} \mathrm{O}_{2}$ with relative membrane permeability. This indicated that the production of ROS is a major factor related to heat injury in maize plants. The heat stress mediated increase in oxidative stress and MDA contents has been reported in cereals such as in wheat (Iqbal et al., 2015; Savicka and Škute, 2010). Loss of membrane integrity is usually measured as a rise in cellular levels of MDA, a byproduct of lipid peroxidation. In this study, it was noted that in both cultivars, there was a high production of $\mathrm{H}_{2} \mathrm{O}_{2}$ in the Ev-5098 under HS stress, which also exhibited the production of MDA (Fig. 4).
Heat shock exhibited a marked effect on the activities of antioxidant enzymes (SOD, POD, CAT and APX) in both maize cultivars. The rise in the activity of SOD was dose dependent in both maize cultivars. However, plants of Pak-Afgoi had a sharp rise in SOD activity, while the increase in the SOD activity was almost negligible compared with control plants of EV-5098 (Fig. 5 and Table 1). Higher POD activity was evident in the EV-5098, while the pattern of increase or decrease in POD activity was erratic in Pak-Afgoi under HS. Rise in POD activity was dose dependent in the EV-5098, where maximal POD activity was recorded in plants exposed to HS for $72 \mathrm{~h}$. In contrast, Pak-Afgoi plants had higher POD activity when exposed to $48 \mathrm{~h}$ of HS. A similar pattern for CAT activity was detected in both maize cultivars. In this regard, consistent rise in CAT activity was evident in the EV-5098, while the pattern of increase or decrease in CAT activity was not consistent in Pak-Afgoi (Fig. 5). Activities of APX enzyme increased consistently in Pak-Afgoi, while there was a not significant effect of HS on this variable in plants of EV-5098.

Parallels can be drawn between the activities of antioxidant enzymes and cellular levels of RMP, MDA and $\mathrm{H}_{2} \mathrm{O}_{2}$. Superoxide dismutase is considered as the first line of defense used by plants to scavenge superoxide radicals into $\mathrm{H}_{2} \mathrm{O}_{2}$ and $\mathrm{O}_{2}$. Hydrogen peroxide is also taken as lethal ROS that must be detoxified (Ashraf et al., 2012). Plants use peroxidases like POD, APX and catalase enzymes scavenge the $\mathrm{H}_{2} \mathrm{O}_{2}$. In present investigation, significantly lesser values for RMP, MDA and $\mathrm{H}_{2} \mathrm{O}_{2}$ in $c v$. Pak-Afgoi could be linked to higher activities of SOD and APX enzymes that effectively detoxified lethal ROS (Fig. 5). Apart from this, proline levels were higher in Pak-Afgoi that would have contributed to ROS scavenging. Proline has also been reported to scavenge reactive oxygen species in wheat exposed to cadmium toxicity (Ashraf and Foolad, 2007).

\section{CONCLUSIONS}

1. Irrespective of exposure time, heat shock stress affected growth and physiochemical attributes in both maize cultivars. The heat shock increased the synthesis of $\mathrm{H}_{2} \mathrm{O}_{2}$ and malondialdehyde contents that resulted in oxidative damage to plants of both cultivars which was evident from higher values of RMP and reduced growth, particularly in the sensitive cultivar.

2 . The heat shock caused a marked increase in the proline accumulation and the activities of antioxidant enzymes.

3. Increasing heat shock duration caused a significant decline in the photosynthetic pigments, total free amino acids and anthocyanin contents particularly in the sensitive cultivar.

4. The cultivar Pak-Afgoi was found to be heat shock tolerant in terms of having lower levels of oxidative stress indicators (relative membrane permeability, $\mathrm{H}_{2} \mathrm{O}_{2}$ and malondialdehyde) and better antioxidative defense system.

5 . The results suggested that oxidative stress indicators can be used as markers to screen heat tolerant crop species. 
Conflict of interest: Authors not declare conflict of interest.

\section{REFERENCES}

Agati G., Matteini P., Goti A., and Tattini M., 2007. Chloroplastlocated flavonoids can scavenge singlet oxygen. New Phytologist, 174, 77-89, doi: 10.1111/j.1469-8137.2007.01986.x

Ashraf M. and Hafeez M., 2004. Thermotolerance of pearl millet and maize at early growth stages: growth and nutrient relations. Biologia Plantarum, 48(1), 81-86, doi: 10.1023/ B:BIOP.0000024279.44013.61

Ashraf M. and Foolad MR., 2007. Roles of glycinebetaine and proline in improving plant abiotic stress resistance. Environ. Exp. Bot., 59, 206-216, doi.org/10.1016/j.envexpbot. 2005.12.006

Ashraf M.Y., Hussain F., Ashraf M., Akhter J., and Ebert G., 2012. Modulation in yield and juice quality characteristics of citrus fruit from trees supplied with zinc and potassium foliarly. J. Plant Nutrition, 34, doi: 10.1080/01904167. 2013.808668

Balakhnina T.I., Kosobryukhov A.A., Ivanov A.A., and Kreslavskii V.D., 2005. The effect of cadmium on $\mathrm{CO}_{2}$ exchange, variable fluorescence of chlorophyll, and the level of antioxidant enzymes in pea leaves. Russian J. Plant Physiology, 52, 15-20, doi: 10.1007/s11183-005-0003-z

Bates I.S., Waldren R.P., and Teare L.D., 1973. Rapid determination of free proline for water stress studies. Plant Soil, 39, 205-207, doi: 10.1007/BF00018060

Cakmak I., Strbac D., and Marschner H., 1993. Activities of hydrogen peroxide scavenging enzymes in germinated wheat seeds. J. Experimental Botany, 44, 127-132, doi: $10.1093 / \mathrm{jxb} / 44.1 .127$

Chakraborty U. and Pradhan D., 2011. High temperatureinduced oxidative stress in Lens culinaris, role of antioxidants and amelioration of stress by chemical pre-treatments. J. Plant Interaction, 6, 43-52, doi:10.1080/17429145. 2010.513484

Chutipaijit S., Cha-um S., and Sompornpailin K., 2011. High contents of proline and anthocyanin increase protective response to salinity in Oryza sativa L. spp. Indica. Australian J. Crop Sci., 5, 1191-1198.

Cvikrova' M., Gemperlova' L., Dobra' J., Martincova' O., Pra'sil I.T., Gubis J., and Vanková R., 2012. Effect of heat stress on polyamine metabolism in proline-over-producing tobacco plants. Plant Biology, 182, 49-58, doi: 10.1016/j.plantsci.2011.01.016

Davies B.H., 1976. Carotenoids. In: Chemistry and Biochemistry of Plant Pigments (Ed. T.W. Goodwin), New York, Academic Press London, San Francisco.

Egli D.B., TeKrony D.M., Heitholt J.J., and Rupe J., 2005. Air temperature during seed filling and soybean seed germination and vigor. Crop Sci., 45, 1329-1335, doi:10.2135/ cropsci2004.0029

Farooq M., Bramley H., Palta J.A., and Siddique K.H.M., 2011. Heat stress in wheat during reproductive and grain filling phases. Critical Reviews in Plant Sci., 30, 491-507, doi:10.1080/07352689.2011.615687
Gill S.S. and Tuteja N., 2010. Reactive oxygen species and antioxidant machinery in abiotic stress tolerance in crop plants. Plant Physiology Biochemistry, 48(12), 909-930, doi:10. 1016/j.plaphy.2010.08.016

Gong H., Zhu X., Chen K., Wang S., and Zhang C., 2005. Silicon alleviates oxidative damage of wheat plants in pots under drought. Plant Sci., 169, 313-321, doi:10.1016/j. plantsci.2005.02.023

Gosavi G.U., Jadhav A.S., Kale A.A., Gadakh S.R., Pawar B.D., and Chimote V.P., 2014. Effect of heat stress on proline, chlorophyll content, heat shock proteins and antioxidant enzyme activity in sorghum (Sorghum bicolor) at seedlings stage. Indian J. Biotechnol., 13(3), 356-363, http://hdl.handle.net/123456789/29616

Hamilton P.B. and Van Slyke D.D., 1943. Amino acid determination and metal accumulation by Brassica juncea L. Int. J. Plant Production, 3(1), 1735-8043.

Hasanuzzaman M., Nahar K., Alam Md. M., Roychowdhury R., and Fujita M., 2013. Physiological, biochemical, and molecular mechanisms of heat stress tolerance in Plants. International J. Molecular Sci., 14, 9643-9684, doi: 10.3390/ijms 14059643

Hayat S., Hayat Q., Alyemeni M.N., Wani A.S., Pichtel J., and Ahmad A., 2012. Role of proline under changing environments: a review. Plant Signaling Behavior, 7(11), 1456-1466, doi: 10.4161/psb.21949

Heath R.L. and Packer L., 1968. Photoperoxidation in isolated chloroplasts. Archives of Biochemistry and Biophysics, 125, 189-198, doi: 10.1016/0003-9861(68)90654-1

Hodges D.M. and Nozzolillo C., 1996. Anthocyanin and anthocyanoplast content of cruciferous seedlings subjected to mineral nutrient deficiencies. J. Plant Physiol., 147, 749754, doi: 10.1016/S0176-1617(11)81488-4

Hurkman W.J., Vensel W.H., Tanaka C.K., Whitehand L., and Altenbach S.B., 2009. Effect of high temperature on albumin and globulin accumulation in the endosperm proteome of the developing wheat grain. J. Cereal Sci., 49, 12-23. doi: 10.1016/j.jcs.2008.06.014

Iken J.E., Amusa N.A., and Obatolu V.O., 2002. Nutrient composition and weight evaluation of some newly developed maize varieties in Nigeria. J. Food Technology in Africa, 7, 27-29.

IPCC, 2007. Fourth Assessment Report. Cambridge University Press, Cambridge, UK.

Iqbal M. and Ashraf M., 2010. Changes in hormonal balance: A possible mechanism of pre-sowing chilling-induced salt tolerance in spring wheat. J. Agronomy Crop Sci., 196, 440-454, doi: 10.1111/j.1439-037X.2010.00434.x

Iqbal M., Hussain I., Liaqat H., Ashraf M.A., Rasheed R., and Rehman A.U., 2015. Exogenously applied selenium reduces oxidative stress and induces heat tolerance in spring wheat. Plant Physiology Biochemistry, 94, 95-103, doi: 10.1016/j.plaphy.2015.05.012

Kaushal N., Gupta K., Bhandhari K., Kumar S., Thakur P., and Nayyar H., 2011. Proline induces heat tolerance in chickpea (Cicer arietinum L.) plants by protecting vital 
enzymes of carbon and antioxidative metabolism. Physiology Molecular Biology Plants, 17, 203-213, doi: 10.1007/s12298-011-0078-2

Krivosheeva A., Tao D.L., Ottander C., Wingsle G., Dube S.L. and Oquist G., 1996. Cold acclimation and photoinhibition of photosynthesis in Scots pine. Planta, 200, 296-305, doi: 10.1007/BF00200296

Lobell D.B. and Field C.B., 2007. Global scale climate-crop yield relationships and the impacts of recent warming. Environmental Research Letters, 2, 014002, doi:10.1088/ $17489326 / 2 / 1 / 014002$

Mahmood S., Parveen A., Hussain I., Javed S., and Iqbal M., 2014. Possible involvement of secondary metabolites in the thermotolerance of maize seedlings. Int. J. Agriculture Biology, 16(6), 1075-1082.

Perveen A., Hussain I., Rasheed R., Mahmood S., and Wahid A., 2013. Growth bioregulatory role of root-applied thiourea: changes in growth, toxicity symptoms and photosynthetic pigments of maize. Pakistan J. Agric.Sci., $50,455-462$.

Rahman M.A., Chikushi J., Yoshida S., and Karim A.J.M.S., 2009. Growth and yield components of wheat genotypes exposed to high temperature stress under control environment. Bangladesh J. Agric. Res., 34, 361-372, doi: http:// dx.doi.org/10.3329/bjar.v34i3.3961

Rasheed R., Ashraf M.A., Hussain I., Parveen A., Alam R., Iqbal M., 2015. Physiological and biochemical markers to optimize sugar mill wastewater for irrigation in maize (Zea mays L.) crop. Brazilian J. Botany, 38, 51-61, doi: 10.1007/ s40415-014-0122-x

Reshmi G.R. and Rajalakshmi R., 2012. Drought and UV stress response in Spilanthes acmella Murr. (tooth-ache plant). J. Stress Physiology Biochemistry, 8(4), 110-129.

Riley G.J.P., 1981. Effects of high temperature on protein synthesis during germination of Maize. Planta, 151, 75-80
Rodríguez M., Canales E., and Borrás-Hidalgo O., 2005. Molecular aspects of abiotic stress in plants. Biotecnology Aplicada, 22, 1-10.

Sarkis J.R., Jaeschke D.P., Tessaro I.C., and Marczak L.D.F., 2013. Effects of ohmic and conventional heating on anthocyanin degradation during the processing of blueberry pulp. LWT - Food Science Technology, 51, 79-85, doi: 10.1016/j. lwt.2012.10.024

Savicka M. and Škute N., 2010. Effects of high temperature on malondialdehyde content, superoxide production and growth changes in wheat seedlings (Triticum aestivum L.). Ekologija, 56, 26-33, doi: 10.2478/v10055-010-0004-x

Simon-Sarkadi I., Kocsy G., Varhegyi A., Galiba G., and de ronde JA., 2005. Genetic manipulation of proline accumulation influences the concentrations of other amino acids in soybean subjected to simultaneous drought and heat stress. J. Agric. Food Chemistry, 53, 7512-7517, doi: 10.1021/ jf0505401

Velikova V., Yordanov I., and Edreva A., 2000. Oxidative stress and some antioxidant systems in acid rain treated bean plants. The protective role of exogenous polyamines. Plant Sci., 151, 59-66, doi: 10.1016/S0168-9452(99)00197-1

Weisany W., Sohrabi Y., Heidari G., Siosemardeh A., and Golezani K.G., 2012. Changes in antioxidant enzymes activity and plant performance by salinity stress and zinc application in soybean (Glycine $\max$ L.). Plant Omics J., 5(2), 60-67.

Yang G., Rhodes D., and Joly R.J., 1996. Effect of high temperature on membrane stability and chlorophyll fluorescence in glycine betaine-deficient and glycine betaine containing maize cultivars. Australian J. Plant Physiology, 23, 437443, doi: 10.1071/PP9960437

Yoshida S., Forno D.A., Cock J.H., and Gomez K.A., 1976. Laboratory Manual for Physiological Studies of Rice. IRRI, Los Banos. 